\title{
Phylogeny of the Rhyparini and the new tribe Stereomerini, with descriptions of new genera and species (Coleoptera; Scarabaeidae; Aphodiinae)
}

\author{
HENRY F. HowdEN \\ Department of Biology, Carleton University, Ottawa, Ont., Canada KlS $5 B 6$ \\ AND \\ ROSS I. STOREY \\ Department of Primary Industries, P.O. Box 1054, Mareeba, Queensiand, Australia 4880 \\ Received November 26, 1991 \\ Accepted March 25, 1992
}

\begin{abstract}
Howden, H. F, and Storex, R. I. 1992. Phylogeny of the Rhyparini and the new tribe Stereomerini, with descriptions of new genera and species (Coleoptera; Scarabaeidae; Aphodiinae). Can. J. Zool. 70: 1810-1823.

A new tribe, the Stereomerini, is established for four unusual genera: Stereomera Arrow, Termitaxis Krikken, Australoxenella n.gen., and Bruneixenus n.gen. The previously described genera are monotypic, as is Bruneixenus, the type species being $B$. squamosus n.sp. from Brunei. Australoxenella contains two new species, A. humptydooensis, type species, and A. bathurstensis, both from the Northern Territory, Australia. The relationships of the new tribe are analyzed and compared with the most closely related tribe, the Rhyparini, in the Aphodiinae. The tribe Rhyparini is redefined, and the genus Notocaulus Quedenfeldt is transferred to the Eupariini. A key to genera in both the Stereomerini and the Rhyparini is presented, important characters are illustrated, a cladogram is given, and convergence is discussed.
\end{abstract}

Howden, H. F., et Storey, R. I. 1992. Phylogeny of the Rhyparini and the new tribe Stereomerini, with descriptions of new genera and species (Coleoptera; Scarabaeidae; Aphodiinae). Can. J. Zool. 70 : 1810-1823.

Une nouvelle tribu, celle des Stereomerini, a été établie pour regrouper quatre genres très particuliers : Stereomera Arrow, Termitaxis Krikken, Australoxenella n.gen. et Bruneixenus n.gen. Les genres déjà décrits sont monotypiques et Bruneixenus, espèce type B. squamosus n.sp. de Brunei, l'est aussi. Australoxenella contient deux nouvelles espèces, A. humptydooensis, espèce type, et $\boldsymbol{A}$. bathurstensis, toutes deux du Territoire du Nord en Australie. Les relations de la nouvelle tribu sont analysées et comparées à celles de la tribu la plus apparentée, les Rhyparini chez les Aphodiinae. La tribu des Rhyparini est définie de nouveau et le genre Notocaulus Quedenfeldt est transféré dans les Eupariini. On trouvera ici une clé d'identification des genres inclus dans les Stereomerini et les Rhyparini; les principales caractéristiques des genres sont illustrées et un cladogramme est présenté ainsi qu'une discussion sur la convergence.

[Traduit par la rédaction]

\section{Introduction}

Two very unusual, highly modified genera of scarab beetles which we suspect are termitophilous have recently been discovered in northern Australia and in Brunei. These genera, together with two monotypic genera, Stereomera Arrow and Termitaxis Krikken, previously included in the tribe Rhyparini in the subfamily Aphodiinae, are placed in a new tribe which is related to the Rhyparini. Unusually modified termitophilous or myrmecophilous scarabs are often difficult to classify, as noted both by Arrow (1905) and Krikken (1970). Arrow stated (1905, p. 536) that "the domestic animals of ants [and we would include termites], like those of man, are great violators of the proprieties of systematics." This observation has subsequently been borne out by the different classifications proposed for the supposed termitophilous or myrmecophilous taxa placed in the Aphodiinae (or Aphodiidae of some authors). In general, we have accepted the aphodiine tribes as listed by Rakovič (1987), but we have not attempted to redefine any of the tribes except for the Rhyparini, and a new tribe, the Stereomerini. In our attempt to define these tribes, we examined over 70 characters used by various authors for defining taxa within the Aphodiinae. In defining the relationships between and within the new tribe and the Rhyparini, we have utilized 35 characters, some not previously used, that we feel may indicate monophyly although, as discussed later, some of these characters may be subject to convergence or to different interpretations.

\section{Tribal characters of the Stereomerini and Rhyparini}

In the revision of the Aphodiinae by Schmidt (1922), five tribes are recognized. Subsequently, at least five tribes have been added; see Rakovič (1987) for a reasonably complete list. While there is considerable concordance among recent authors on the tribes, there is less agreement on the characters used to define the tribes. Stebnicka (1985) discusses some of these characters, emphasizing that the mouthparts are particularly useful. Other authors have utilized different characters. Because of the condition of some of the material available to us we did not examine the mouthparts, but some characters we do use in defining the Rhyparini have not been used by others.

The Aphodiinae is a large and diverse group and few, if any, characters used to define either the subfamily or tribes are entirely concordant. In general, the Aphodiinae have a ninesegmented antenna with a three-segmented club, and the body is cylindrical and relatively elongate. The Aphodiini, Eupariini, and Rhyparini, and the new tribe have the labrum and mandibles concealed under the clypeus. Most Eupariini, all the Rhyparini, and the new tribe have lost the transverse carinae on the meso- and meta-tibiae (Fig. 35) that characterize the Aphodiini and some Psammodiini. The meso- and meta-tibiae of the Eupariini are relatively slender and the two apical tibial spurs (Fig. 33) strongly developed.

Characters used to define the tribe Rhyparini since it was first proposed by Schmidt (1910) have usually been limited to one or two obvious structures, such as the presence of longitu- 
dinal ridges on the pronotum. Because many of the included genera are unusually modified, the defining characters have varied as new genera have been added since Westwood's description of Rhyparus (for a discussion on the date of publication and spelling of the original name see Cartwright and Woodruff 1969). Tangelder and Krikken (1982) and Rakovič (1987) have resolved some of the problems encountered in defining the tribes in the Aphodiinae, but both the tribal definitions and the generic relationships within all of the tribes need further assessment. This is beyond the scope of this paper, our analysis being restricted to the genera formerly placed in the Rhyparini.

\section{Shared characters}

The rhyparine genera now placed in either the Rhyparini or the Stereomerini have the following characters in common. Body small, 1.5-7.0 $\mathrm{mm}$ in length. Eyes concealed under pronotal edge when head is in retracted position; eyes reduced or absent in some genera. Pronotum and elytra longitudinally costate or carinate. Pronotum with transverse sulcus indicated, except in Sybacodes Fairmaire. Scutellum minute or absent. Prosternal process lanceolate or hastate medially, posterior to prosternal coxae (Figs. 6, 24). Protibia with teeth often reduced in number, two teeth frequently present on or near apex. Meso- and meta-tibiae lacking transverse carinae, apical spurs small or absent.

\section{Tribe Rhyparini (Schmidt, 1910)}

Clypeus at least feebly bidentate, sometimes quadridentate, anterior edge somewhat inflexed, medially with edge sharply, obtusely angulate. Frons and vertex with tufts of setae or longitudinal tubercles. Pronotum with six longitudinal costae or carinae equally spaced on disc. Elytra costate, costae vary- ing in height, number, and spacing; elytral apices frequently bulbous. Elytral epipleura narrow. Prosternal process medially hastate posterior to coxae (Fig. 24), with lateral projections overlapping modified apex of mesofemur (Fig. 21), thus acting as a locking device. Outer posterior part of metasternum on each side frequently with small projection or peg (Figs. 22, 26) that seemingly acts as a locking device for the metafemur. Meso- and meta-tibiae oval in cross section, not distinctly flattened. Tarsomeres 5-5-5, basal meso- and metatarsomeres longer than next one or two segments.

TYPE GENUS: Rhyparus Westwood, 1845.

\section{Stereomerini new tribe}

Clypeus not dentate on each side near gena, inflexed edge medially angulate or not. Frons and vertex with three or more longitudinal grooves; surface not tuberculate. Pronotum with longitudinal costae concentrated in median third, a conical swelling present either just anterior to or just posterior to transverse sulcus. Elytral apices rounded, explanate or abruptly declivous, not bulbous; inflexed sides of elytra (epipleura) wide. Prosternal process posterior to coxae more or less lanceolate, lacking strong lateral projections (Fig. 18); locking devices for mesoand meta-femora lacking. Meso- and meta-tibiae and femora flattened. Tarsomeres 5-5-5 or 5-4-4, the latter often appearing as 5-3-3; meso- and meta-tarsi short, particularly basal tarsomere, this rarely longer than next segment, usually shorter.

TYPE GENUS: Stereomera Arrow, 1905.

\section{Remarks}

In his description of Stereomera pusilla, Arrow (1905) mentions the meso- and meta-tarsomere counts as being 3-3. The number is actually $4-4$ with a minute basal tarsomere in each tarsus (Fig. 19).

\section{Key to the genera in the Rhyparini and Stereomerini}

1. Posterior prosternal process hastate (Fig. 24). Metatibia more or less oval in cross section; basal tarsomere longer than next two

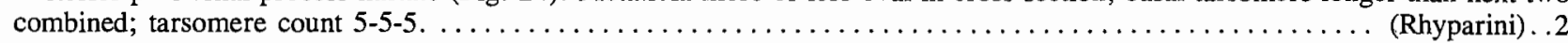
Posterior prosternal process lanceolate (Fig. 6). Metatibia flattened; basal tarsomere distinctly shorter than next two combined. Tarsomere count frequently reduced, i.e., 5-4-4 (or appears to be 5-3-3) .................. (Stereomerini)..5

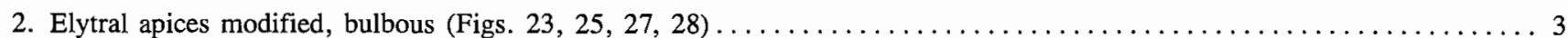

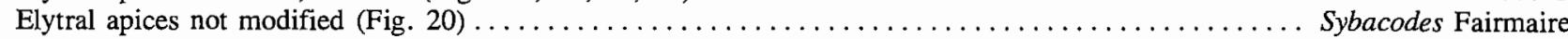

3. Sides of pronotum trilobed, base strongly constricted; elytra with strongly elevated costae, sides of elytra converging in posterior

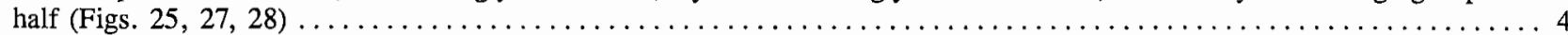
Sides of pronotum bilobed, base of pronotum not strongly constricted; elytra with costae not strongly elevated, sides of elytra almost

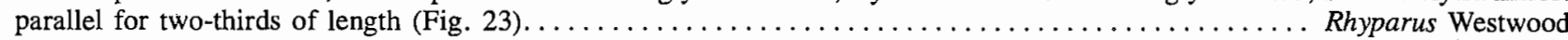

4. Pronotal ridges strongly elevated; dorsum not closely, uniformly punctate (Figs. 25, 27). . . ....... Termitodius Wasmann Pronotal ridges feebly elevated; dorsum closely, uniformly punctate (Fig. 28)............... Termitodiellus Nakane

5. Elytra on disc lacking strong transverse ridges between costae; elytra posteriorly not abruptly declivous. .........6 6 Elytra on disc with strong transverse ridges between costae (Fig. 15); elytra posteriorly abruptly declivous (Fig. 17). ...... .

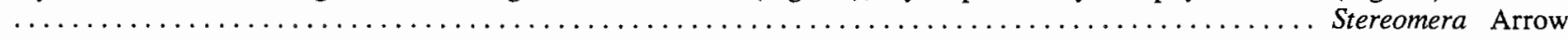

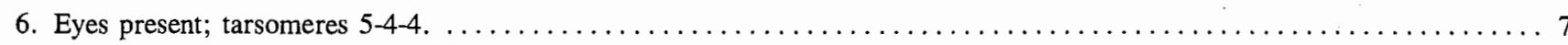

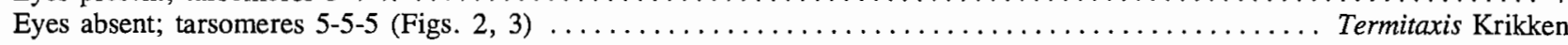

7. Elytral costae moderate to wide; elytral apices conjointly rounded (Fig. 4) . . . . . . . . . .... Australoxenella n.gen. Elytral costae narrow; elytral apices separately rounded (Fig. 11) $\ldots \ldots \ldots \ldots \ldots \ldots \ldots \ldots \ldots$ Bruneixenus n.gen.

\section{Australoxenella n.gen.}

Figs. 1, 4-10

Head (Fig. 4) dorsally broad, about $2 \times$ as wide as long. Clypeus anteriorly with broadly inflexed edge, obtusely angu- late medially. Head dorsally feebly and irregularly convex, lacking tubercles; midline distinctly grooved except near anterior edge and with adjacent slightly deeper groove on each side one-third of distance to outer edge of gena; lateral 


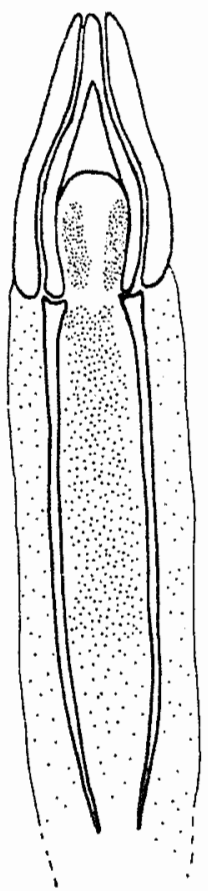

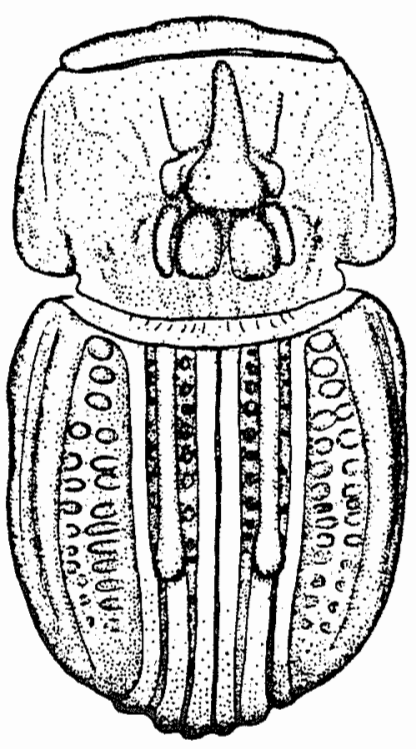

2

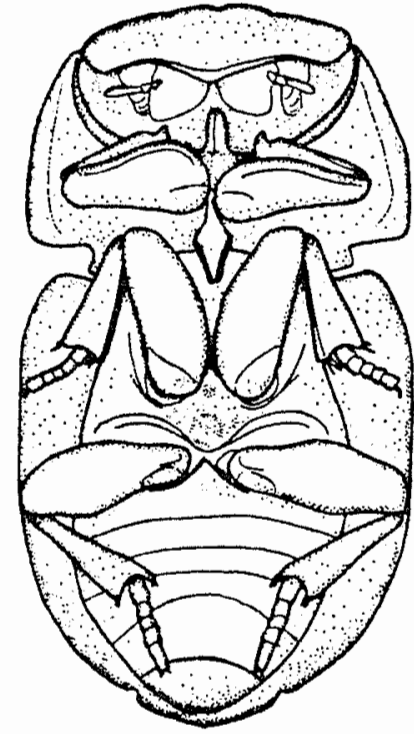

3

Figs. 1-3. Fig. 1. Australoxenella humptydooensis n.sp., male genitalia, dorsal view. Figs. 2 and 3. Termitaxis holmgreni Krikken, after Krikken (1972). Fig. 2. Dorsal view. Fig. 3. Ventral view.

grooves slightly convergent anteriorly; surface of head, except for grooves, with close, appressed circular scales giving granulate appearance. Gena not obviously delimited, inner edge indicated by small, nongranulate area near summit of convex area; outer posterior part of gena ventrally reflexed, surface shining, feebly punctate.

Pronotum (Fig. 8) strongly, irregularly convex with a transverse sulcus near middle; median third anterior to sulcus with seven longitudinal grooves, three inner grooves narrow, middle one on each side wider, becoming more so anteriorly; surface on each side of median groove elevated, more strongly so just anterior to transverse sulcus; equivalent median surface posterior to sulcus with only a trace of a median groove, strongly convex and more strongly elevated than any other part of dorsum; three lateral grooves on each side narrow, parallel, and extending into transverse sulcus; transverse sulcus extending on each side to anterior lateral thirds, each end widened; pronotum laterally with sides almost parallel; anterior angles slightly acute, posterior angles almost rightangled, abruptly rounded; pronotal surfaces with circular scales except alutaceous in depressions. Scutellum minute, surface shining.

Elytron (Fig. 4) strongly ridged on disc, sutural and three other intervals elevated with deep U-shaped depressions between; distinct striae absent except for one below feeble humeral umbone that merges with lateral bead near middle of lateral edge; epipleura broadly inflexed, longitudinally concave near metacoxae; elytral apices not greatly modified, conjointly broadly rounded; ridges on disc with scales and numerous minute setae; depressions dull, alutaceous. Metathoracic wings long, functional.

Pygidium (Fig. 9) ventral, flattened, wider than long, with broadly rounded apex anterior in position. Antenna ninesegmented; club (Fig. 5) three-segmented, equal in length to basal six segments of antenna combined; area surrounding antenna deeply concave. Mentum medially concave, anterior margin almost straight with small median projection. Maxillary palpus apparently three-segmented, apical segment lanceolate, narrowed in apical two-thirds to sharply acute apex. Mandibles thin, bladelike. Eye small, somewhat triangular, approximately 10 facets long $\times 18$ wide. Prosternum laterally with alutaceous surface, anterior edge near antennae with double, raised marginal beads; median prosternal process anteriorly strongly elevated, apex expanded; process posteriorly (Fig. 6) lanceolate. Mesosternum moderate in size, triangular, narrowed laterally. Metasternum between mesocoxae narrow, bladelike; posterior to mesocoxae abruptly widened, flat, shallowly concave in posterior median half, surface alutaceous; metacoxae contiguous. Abdomen with four or five visible segments medially, apical segment longer at centre than other segments combined. Profemur flattened, approximately two-thirds as wide as long; other femora similarly flattened, wide. Protibia with two teeth on outer edge, one apical, one subapical. Meso- and meta-tibiae flattened, width slightly less than onehalf length; outer narrow edge of each tibia with three irregular longitudinal rows of punctures, each puncture with minute yellowish seta; each tibia with two minute apical spurs which may be only large setae; small apical setae also present. Protarsus five-segmented, with several conspicuous setae at ventral apex of each tarsomere, claws normal. Meso- and meta-tarsi apparently four-segmented, basal segment short, no longer than adjacent segment; tarsal claws slightly reduced in thickness.

TYPE SPECIES: Australoxenella humptydooensis n.sp.

\section{Remarks}

Australoxenella is most closely related to the new genus Bruneixenus described below. The characters useful in separating the two genera are given in the Remarks section under Bruneixenus. Two other genera, Stereomera and Termitaxis, show some affinities with Australoxenella, but can be distinguished by the characters given in the key.

Two species are presently placed in Australoxenella. These may be distinguished as follows: 
Transverse pronotal sulcus distinctly widened laterally (Fig. 4), sulcus medially without dense setae; elytral costae on disc narrow;

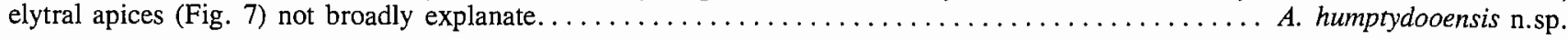

Transverse pronotal sulcus not distinctly widened laterally (Fig. 8), sulcus medially with dense setae; elytral costae on disc wide,

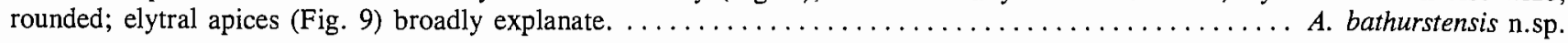

\section{Australoxenella humptydooensis n.sp.}

Figs. 1, 4-7

\section{Holotype}

Male, Australia, Northern Territory, $6 \mathrm{~km}$ E Humpty Doo, 6-19.X.1990, R. I. Storey, at uv light, in Queensland Museum (Type No. T.12146), Brisbane.

Length $2.6 \mathrm{~mm}$, greatest width $1.4 \mathrm{~mm}$. Brown dorsally, reddish brown ventrally. Vertex with the three grooves equal in length. Pronotum (Fig. 4) in anterior half with the two inner costae strongly elevated just anterior to transverse sulcus, these two median costae distinctly higher posteriorly than costa on each side; sulcus as described in key. Elytral costae (Fig. 4) on disc abruptly rounded at top; apex of elytron very narrowly explanate; inflexed ventral edge of each elytron (Fig. 7) tapered posteriorly to narrow apex (in ventral view). Genitalia as in Fig. 1.

\section{Remarks}

The characters mentioned in the key to the species under the generic description will separate $A$. humptydooensis from the only other species in the genus, $A$. bathurstensis.

The specimen of $A$. humptydooensis was taken in a uv light trap suspended approximately $2 \mathrm{~m}$ above the ground in open, dry (at that time), sclerophyll forest. There is no doubt that the specimen flew into the trap.

\section{Australoxenella bathurstensis n.sp.}

Figs. $8-10$

\section{Holotype}

Sex not determined. Australia, Northern Territory, Bathurst Island, Cape Fourcroy, 26.X - 3.XI.1979, P. Horner and I. Archibald, in Northern Territory Museum of Arts and Sciences (Type No. I-287), Darwin.

Length $3.2 \mathrm{~mm}$, greatest width $1.6 \mathrm{~mm}$. Brown dorsally, reddish brown ventrally. Vertex with median groove slightly longer than groove on each side. Pronotum (Fig. 8) in anterior half with the two inner costae only slightly more elevated posteriorly and scarcely more elevated than costa on each side. Elytral costae on disc rounded; apex of elytron broadly explanate (Fig. 10); inflexed ventral edge of each elytron (Fig. 9) not noticeably narrowed near apex.

\section{Remarks}

The species description lists the distinguishing characters. While there are no details of how the specimen was collected, it appears that the species may be active during the dry season and is able to fly.

\section{Bruneixenus n.gen.}

Figs. $11-14$

Head dorsally broad, about $2 \times$ as wide as long. Clypeus with broadly inflexed edge obtusely angulate medially. Vertex feebly concave in median third, lacking tubercles; vertex with five narrow grooves, one median and two on each side, equally spaced between centre and lateral edge, grooves anteriorly divergent; surface, except for grooves, with close, appressed, broadly lanceolate scales. Gena not well defined, ridged just anterior to eye, ridge abutting prothoracic edge.

Pronotum (Fig. 11) irregularly convex with transverse sulcus near middle; median fifth of pronotum anterior to sulcus conical, longitudinally grooved on each side and with second parallel groove on each side near inner third of pronotum; surface longitudinally ridged and elevated posterior to transverse sulcus on each side of grooved midline (distinctly less elevated than anterior conical protrusion), with two lower, feebly convex ridges present on each side of inner ridges, these defined by setose grooves; lateral to these the transverse sulcus on each side curves posteriorly, ending in notch at lateral third of posterior pronotal margin; most of pronotal surface with numerous appressed, broadly lanceolate scales. Scutellum minute.

Elytron (Fig. 11) with four narrow, moderately and evenly elevated costae, these becoming obsolete in apical fifth or sixth; striae not evident, flattened area between costae with two or three longitudinal rows of small scales; laterally elytron gradually rounded to broadly inflexed area (epipleuron not clearly delimited). Elytral sides convergent in apical fourth, gradually depressed, particularly along suture; apex of each elytron (Fig. 13) rounded; elytra not fused (metathoracic wings assumed to be functional).

Pygidium (Fig. 13) ventral, flattened, wider than long, with rounded apex anterior in position. Antenna seemingly ninesegmented, fourth, fifth, and sixth segments small, indistinct, and partly concealed by setae (since sutures are poorly defined, antenna may be eight-segmented); club three-segmented, strongly setose, equal in length to basal six (or five) segments of antenna. Mentum narrowed anteriorly, medially concave. Maxillary palpus apparently three-segmented, apical segment greatly expanded, flattened, with apex acute. Mandibles apically thin. Eye nearly rectangular, about 14 facets long; concealed dorsally by edge of pronotum when head retracted. Prosternum laterally alutaceous, anterior edge near antenna with single marginal bead; median prosternal process anteriorly bladelike, apex only slightly expanded; process posteriorly (Fig. 12) bluntly lanceolate. Mesosternum moderately developed, convex medially, narrowed at sides. Metasternum narrow, apically acute between mesocoxae; posteriorly with midline grooved, metasternum on each side feebly convex. Abdomen (Fig. 13) with five visible segments medially, apical segment at centre almost as long as basal four segments combined. Profemur flattened, about twice as long as wide; other femora similarly flattened, wide. Protibia with two teeth on outer edge, one apical, one subapical. Meso- and meta-tibiae flattened, about two-fifths as wide as long, outer edge of each with four irregular longitudinal rows of scales; mesotibia with small apical spurs (Fig. 14); metatibia lacking distinct spurs, these seemingly replaced by setae. Protarsus five-segmented; claws small, slender. Meso- and meta-tarsi appearing threesegmented, but each with recessed minute basal fourth segment; claws small, slender.

TYPE SPECIES: Bruneixenus squamosus n.sp. 



FIGs. 4-7. Australoxenella humptydooensis n.sp. Fig. 4. Dorsolateral view. Fig. 5. Antennal club. Fig. 6. Prosternal process. Fig. 7. Elytral margin, ventral view. Figs. 8-10. Australoxenella bathurstensis n.sp. Fig. 8. Head and pronotum, dorsolateral view. Fig. 9. Elytral margin and pygidium, ventral view. Fig. 10. Apex of elytra, dorsal view. 

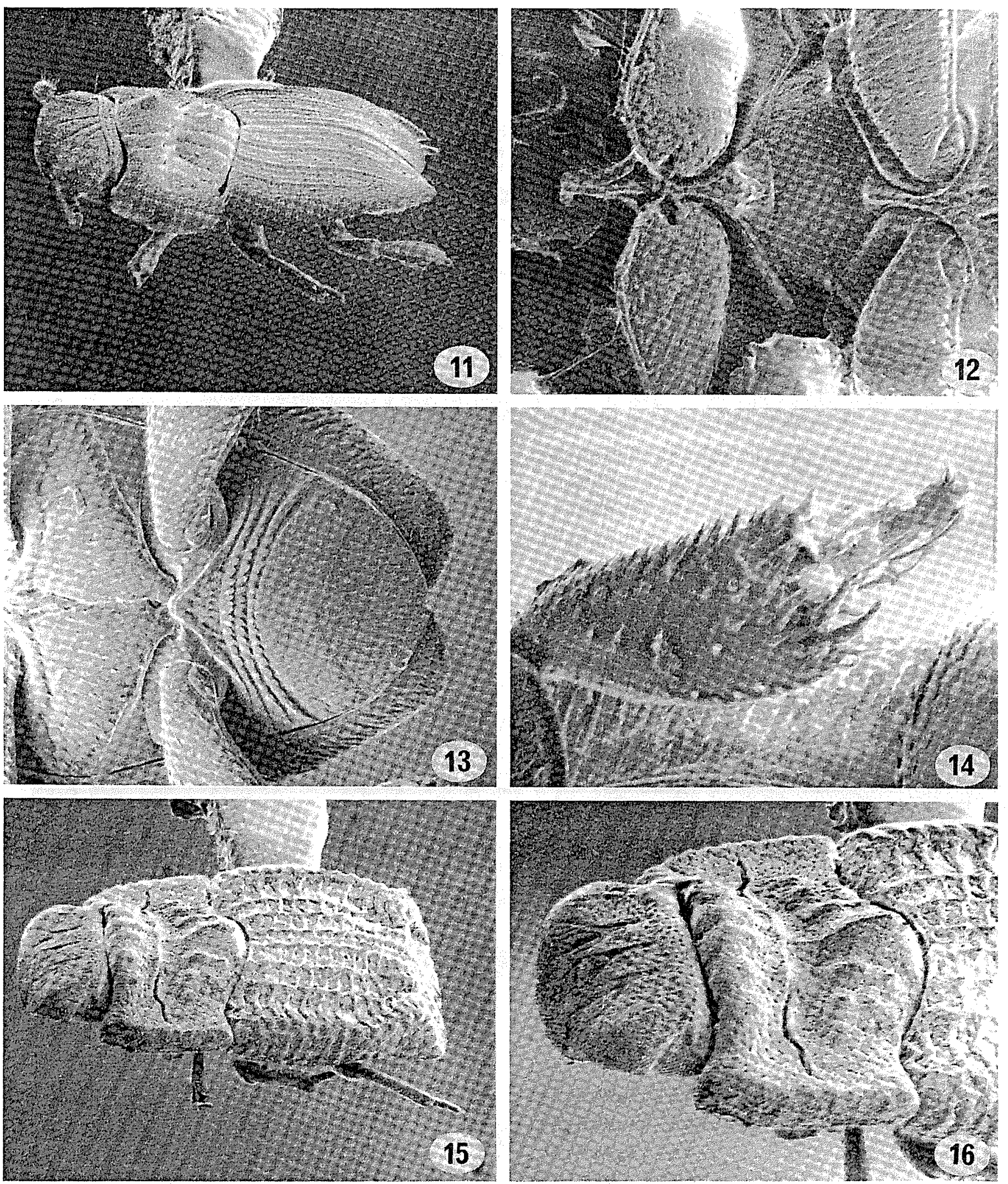

FIgs. 11-14. Bruneixenus squamosus n.sp. Fig. 11. Dorsolateral view. Fig. 12. Prosternal process and metasternum. Fig. 13. Metasternum, abdominal sternites, and pygidium. Fig. 14. Mesotibia. Figs. 15 and 16. Stereomera pusilla Arrow. Fig. 15. Dorsolateral view. Fig. 16. Head and pronotum, dorsolateral view.

\section{Remarks}

The genus most closely related to Bruneixenus is Australoxenella. Size alone will separate the known species in the two genera. However, there are several other obvious characters that distinguish the genera from one another. In Bruneixenus the conical protrusion on the midline of the pronotum is 

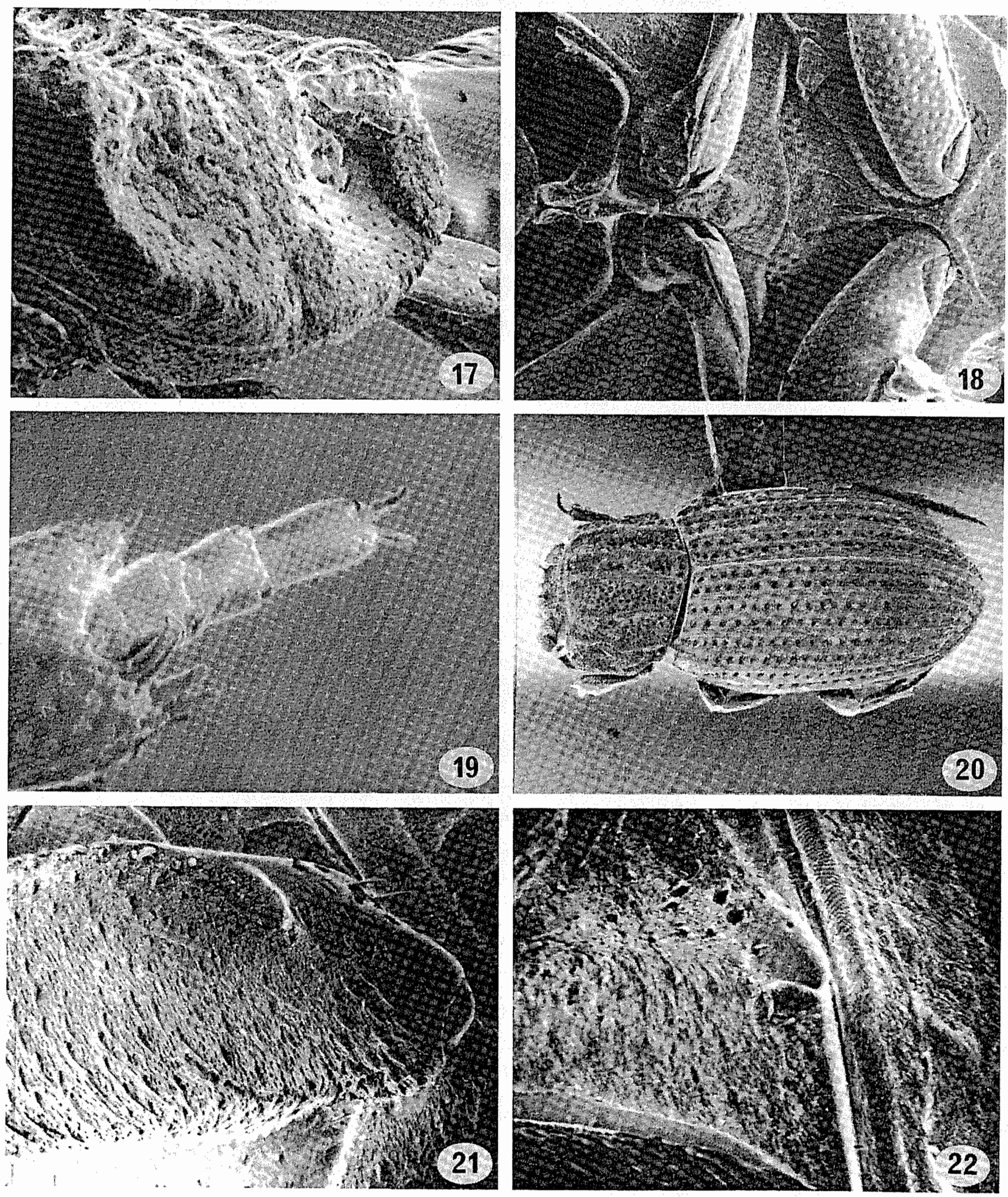

Figs. 17-19. Stereomera pusilla Arrow. Fig. 17. Elytra, apical view. Fig. 18. Prosternal process and metasternum. Fig. 19. Metatibia, apex and tarsus. FIGs. 20-22. Sybacodes lutulentus Fairmaire. Fig. 20. Dorsal view. Fig. 21. Mesofemur, apical edge showing the excavation that fits under the lateral projection of the hastate prosternal process. Fig. 22. Metasternum, lateral edge showing peglike process that may brace the metafemur. 


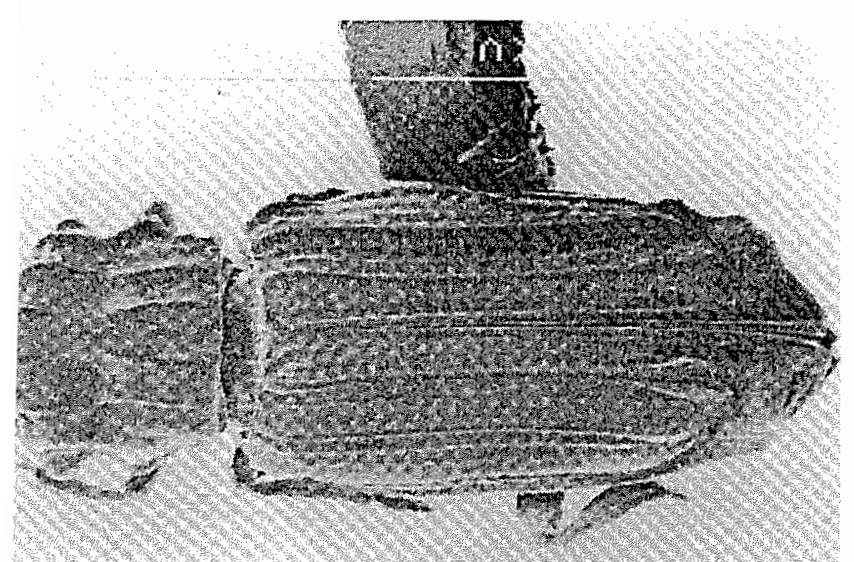

23
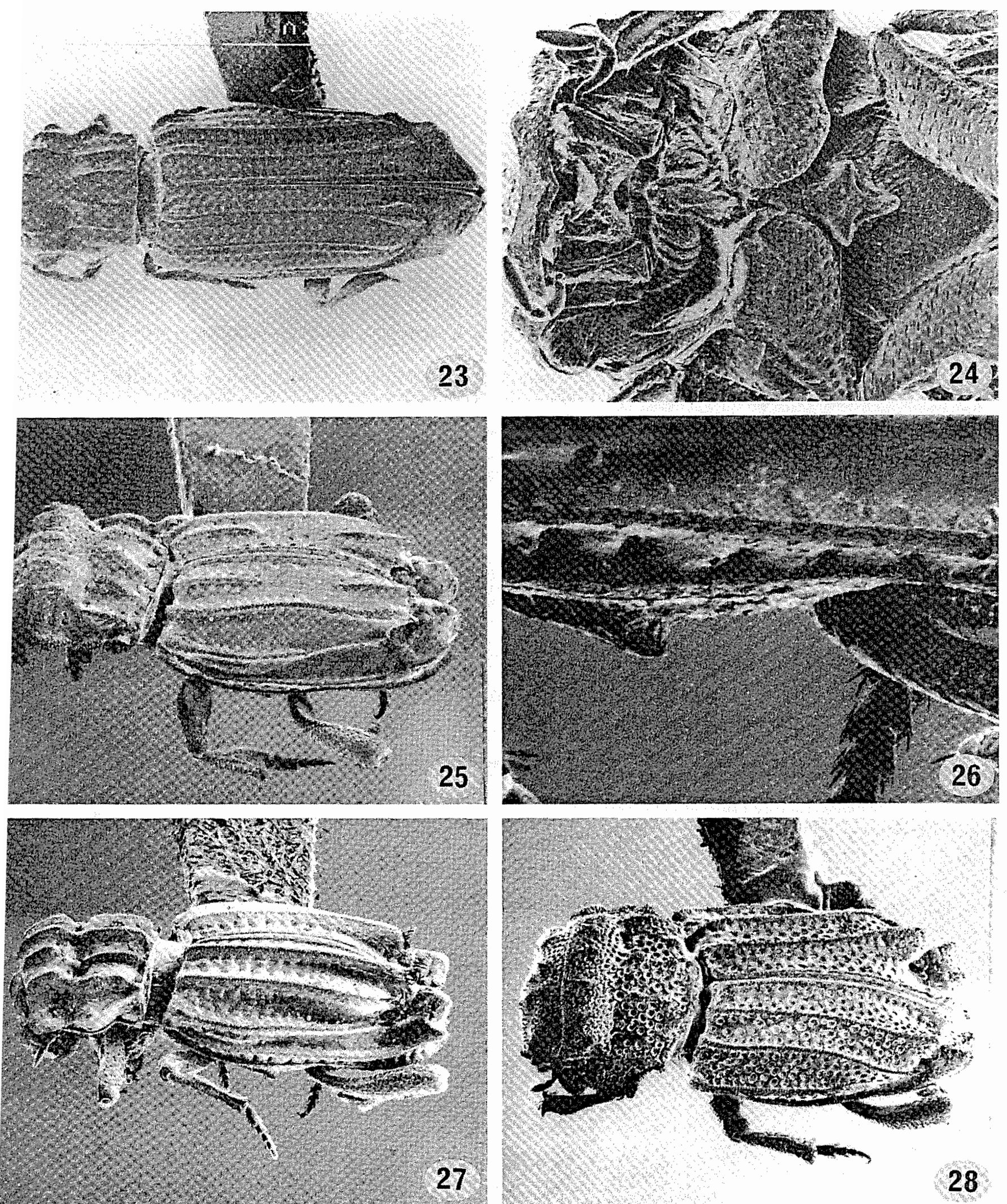

FrGs. 23 and 24. Rhyparus australiae Lea. Fig. 23. Dorsal view. Fig. 24. Prosternal process, showing hastate posterior projection. Figs. $i$ and 26. Termitodius sp. (Sulawesi). Fig. 25. Dorsolateral view. Fig. 26. Metasternal peg, lateral view. FIg. 27. Termitodius peregrinus inton, dorsolateral view. Frg. 28. Termitodiellus esakii Nomura, dorsal view. 



Figs. 29-31. Cartwrightia intertribalis Islas. Fig. 29. Dorsolateral view. Fig. 30. Apex of elytron. Fig. 31. Posterior prosternal process. Figs. 32 and 33. Notocaulus sp. (Kenya). Fig. 32. Head and pronotum, dorsal view. Fig. 33. Mesotibia, apex showing spurs. Figs. 34 and 35. Sybax sulcicollis Boheman. Fig. 34. Lateral view. Fig. 35. Metatibia, showing transverse carinae. 
anterior to the transverse sulcus, whereas in Australoxenella it is posterior. Also, in Bruneixenus the apex of each elytron is separately rounded; in Australoxenella the elytra are conjointly rounded with a slight notch at the suture. Other differences occur in the elytral ridges, in the midline of the metasternum, and in the degree of flattening of the tibiae.

\section{Bruneixenus squamosus n.sp.}

Figs. 11-14

\section{Holotype}

Sex not determined. Brunei, Rampayoh R., Upper Waterfall, 1-4.III.1982, M. V. Day, in The Natural History Museum, formerly the British Museum (Natural History), London.

Length $1.7 \mathrm{~mm}$, greatest width $0.85 \mathrm{~mm}$. Light brown to brown; dorsal surfaces, except for grooves, with numerous appressed or semi-recumbent, broadly lanceolate, pale scales; distance between scales approximately equal to width of one scale. Morphology as in generic description. Ventrally metasternum, abdomen, and ventral surface of femora all with appressed scales, scales separated by a distance equal to two or three times width of one scale.

\section{Remarks}

The characters mentioned in the generic description also distinguish the species, since the genus, at present, is monotypic.

\section{Characters selected for analysis}

Because of the thousands of species and more than 100 genera and subgenera described in the Aphodiinae, we have restricted our character analysis to those genera that we currently place in the Rhyparini and Stereomerini. Though we examined the other tribes in the Aphodiinae, we utilized only common (free living, not inquiline) Eupariini, mostly in the genus Ataenius Harold, as the out-group using the "out-group comparison method" as described by Watrous and Wheeler (1981) for polarizing character states. We initially examined 70 characters of which we now consider 35 to be of possible use. These 35 characters are listed in Table 1; Table 2 scores the character states for each of the taxa considered. The definitive, raised, lanceolate or hastate posterior prosternal projection has not been included in our analysis, as we are uncertain of the origin or polarization of its character states. There are some vaguely similar structures in some Australian Eupariini and in some Psammodiini, but typically the Eupariini have a flattened, triangular posterior prosternal process similar to that of Cartwrightia Islas (Fig. 31).

Characters whose apomorphic state seems to have evolved only once appear to be rare, at least in the Aphodiinae. Apomorphic character states that seem to have evolved more than once generally, but not always, involve reduction, and the parallelism that results from independent reductions makes it difficult to assess some shared similarities. Some possibly independent reductions that appear in the various tribes in the Aphodiinae involve loss of carinae on tibiae, reduction or loss of tarsal spurs (character 33 in Table 1), reduction in tarsal length or in length or number of some tarsomeres (34), reduction in eye size (4), reduction in number of teeth on the protibia (30), reduction in size of scutellum (13), and various types of reduction of the metathoracic wings (24). While some uncertainty exists in using these characters and their various states in phylogenetic analysis, using them within the limited scope of our present study lessens the chance of failing to detect multiple reductions, particularly when there is concordance with other synapomorphies.

While multiple reductions can cause problems in interpretation, using characters that have developed independently on several occasions can also lead to confusion. Examples of independent development are found in the elevated elytral costae or ridges, in the pronotal costae, and occasionally in the bulbous swelling near the elytral apices. All of these characters may occur in unrelated genera belonging to different tribes. For example, elytral costae or ridges occur in Sybax Boheman (Fig. 34) (Aphodiini); both pronotal and elytral costae occur in Notocaulus Quedenfeldt (Fig. 32) (Eupariini) and Rhyparus (Fig. 23) (Rhyparini); and ridges and the bulbous elytral apices with trichomes occur in Cartwrightia (Figs. 29, 30) (Eupariini) and Termitodius Wasmann (and some other Rhyparini). One further complication in determining generic relationships within the Rhyparini is the current taxonomic confusion in defining genera; both Rhyparus and Termitodius are in need of a careful review on a worldwide basis. However, even after these genera are revised, the tribal definition as given here should remain unchanged.

In our analysis of character states we found few structures unique to either the Rhyparini or the Stereomerini other than the posterior prosternal process. Characters of the head (1-3 in Table 1) differ in the two tribes. The grooves found in the Stereomerini are seemingly unique; the tubercles found in the Rhyparini vaguely resemble those occurring in some genera of Eupariini. Eyes (4) are often influenced by habits; reductions are not uncommon in unrelated taxa. Also, unrelated taxa may have lanceolate palpomeres (5). Long segments in the antennal club (6) that occur in most Stereomerini are unusual in the Aphodiinae, the reduction in Termitaxis probably representing a homoplasy.

Pronotal characters $7,8,9,11$, and 12 vary between the Rhyparini and the Stereomerini. The transverse groove (10), while only partial in Sybacodes and some Rhyparus, is apparently unique to the two tribes. Sybacodes has the outer pronotal ridge on each side obsolete near the middle, while the next inner ridge on each side is slightly interrupted near the middle by a moderate-sized puncture; the innermost pair of ridges (one on each side of the midline) is complete. In Rhyparus, most species have the innermost pair of ridges complete, but in others the ridges are reduced in height or obsolete near the anterior third. In the remaining rhyparine genera and in all the Stereomerini, all of the ridges are distinctly interrupted by a transverse sulcus.

Reduction in the size of the scutellum (13) is not uncommon in unrelated taxa in the Scarabaeoidea, but it is uncommon in the Aphodiinae.

All elytral characters $(14-24)$ may occur in unrelated scarab taxa with the possible exception of the apomorphic state of characters 14 found in Bruneixenus and 15 in Stereomera. However, combinations of apomorphic elytral character states can be definitive for other genera in the Rhyparini and Stereomerini.

Pygidial characters $(25,26)$ and metasternal character 27 are not unique to any one tribe or even to the Aphodiinae. On the other hand, the apomorphic metasternal "peg," character 28 , is apparently limited to the Rhyparini. In some New World Rhyparus the lateral peg is poorly developed. In species where the peg is obsolete it is impossible to say if it has not developed or if it has been secondarily reduced.

None of the remaining apomorphic character states, 29-35, 
TABLE 1. Characters used in developing the phylogeny (Fig. 36)

\begin{tabular}{|c|c|c|c|}
\hline Character & $\begin{array}{l}\text { Plesiomorphic }(0) \\
\text { Plesiomorphic }(0)\end{array}$ & Transition (1) & $\begin{array}{l}\text { Apomorphic (1) } \\
\text { Apomorphic (2) }\end{array}$ \\
\hline \multicolumn{4}{|c|}{ Head } \\
\hline 1. Vertex & $\begin{array}{l}\text { Evenly convex or with small conical } \\
\text { tubercle }\end{array}$ & & $\begin{array}{l}\text { Longitudinally grooved } \\
\text { (Fig. 8) }\end{array}$ \\
\hline 2. Vertex & Tubercle without setae & & Tufts of setae on tubercles \\
\hline 3. Vertex & $\begin{array}{l}\text { Evenly convex or with small conical } \\
\text { tubercle }\end{array}$ & & $\begin{array}{l}\text { Longitudinally ridged } \\
\text { (Fig. 23) }\end{array}$ \\
\hline 4. Eyes & Large & Small & Absent (Fig. 3) \\
\hline 5. Apical maxillary palpomere & Cylindrical & & Lanceolate (Fig. 5) \\
\hline 6. Antennal club & Lamellae long (Fig. 5) & Moderate & Lamellae short \\
\hline \multicolumn{4}{|c|}{ Pronotum } \\
\hline 7. Sides & Not lobed & 1 or 2 lobes & 3 lobes \\
\hline 8. Posterior angles & Not constricted & & Constricted \\
\hline 9. Longitudinal ridges & Widely spaced (Fig. 23) & & Narrowly spaced (Fig. 8) \\
\hline 10. Ridges & Some complete (Fig. 20) & & $\begin{array}{l}\text { All interrupted by transverse } \\
\text { groove (Fig. } 8 \text { ) }\end{array}$ \\
\hline 11. Ridges & Fairly uniform height (Fig. 23) & & Higher near midline (Fig. 4) \\
\hline 12. Large pits & Absent & Shallow & Deep \\
\hline \multicolumn{4}{|c|}{ Scutellum } \\
\hline 13. Scutellum & Small (minute) & & Absent \\
\hline \multicolumn{4}{|c|}{ Elytron } \\
\hline 14. Elytral apex & Unmodified & & Flattened (Fig. 10) \\
\hline 15. Elytral apex & Unmodified & & Declivous (Fig. 17) \\
\hline 16. Elytral apex & Unmodified & & Bulbous (Fig. 25) \\
\hline 17. Striae & Distinct & Indistinct & Absent \\
\hline 18. Sides & Parallel & & Convergent \\
\hline 19. Costae & Low (Fig. 20) & & High (Fig. 27) \\
\hline 20. Costae & Sharp (cross section) (Fig. 27) & & Rounded (Fig. 4) \\
\hline $\begin{array}{l}\text { 21. Epipleura (inflexed sides of } \\
\text { elytra) }\end{array}$ & Narrow & & Wide (Fig. 9) \\
\hline 22. Humeral umbone & Strongly elevated & Low & Absent \\
\hline 23. Humeral angle & Rounded & & Angulate \\
\hline 24. Metathoracic wings & Present & & Absent (not functional) \\
\hline \multicolumn{4}{|c|}{ Pygidium } \\
\hline 25. Pygidium & Vertical (normal) & & Ventral (Fig. 9) \\
\hline 26. Pygidium & Rounded & & Sides excavate or modified \\
\hline \multicolumn{4}{|c|}{ Metasternum } \\
\hline 27. Metasternum & Feebly convex each side & & $\begin{array}{l}\text { Concave or with marginal } \\
\text { bead }\end{array}$ \\
\hline 28. Metasternum & Feebly convex each side & & $\begin{array}{l}\text { With lateral peg (Figs. 22, } \\
\text { 26) }\end{array}$ \\
\hline \multicolumn{4}{|c|}{ Abdomen } \\
\hline 29. Segments at midline & Five & & Less than 5 \\
\hline \multicolumn{4}{|c|}{ Legs } \\
\hline 30. Protibia & 3 teeth outer edge & 2 teeth & 1 tooth \\
\hline 31. Mesofemur & Not modified & & Indented near apex (Fig. 21) \\
\hline 32. Meso- and meta-tibiae & Cross section oval & & Flattened (Fig. 7) \\
\hline 33. Meso- and meta-tibiae & Small spur(s) & & $\begin{array}{l}\text { Spurs minute or absent } \\
\text { (Fig. 14) }\end{array}$ \\
\hline 34. Number of tarsomeres & $5-5-5$ & & $\begin{array}{l}\text { 5-4-4 (some appear 5-3-3) } \\
\text { (Fig. 19) }\end{array}$ \\
\hline \multicolumn{4}{|c|}{ Body shape (in Rhyparini and Stereomerini) } \\
\hline $\begin{array}{l}\text { 35. } 2.4 \times \text { longer than wide or } \\
\text { less }\end{array}$ & & & $\begin{array}{l}2.6 \times \text { longer than wide or } \\
\text { more }\end{array}$ \\
\hline
\end{tabular}



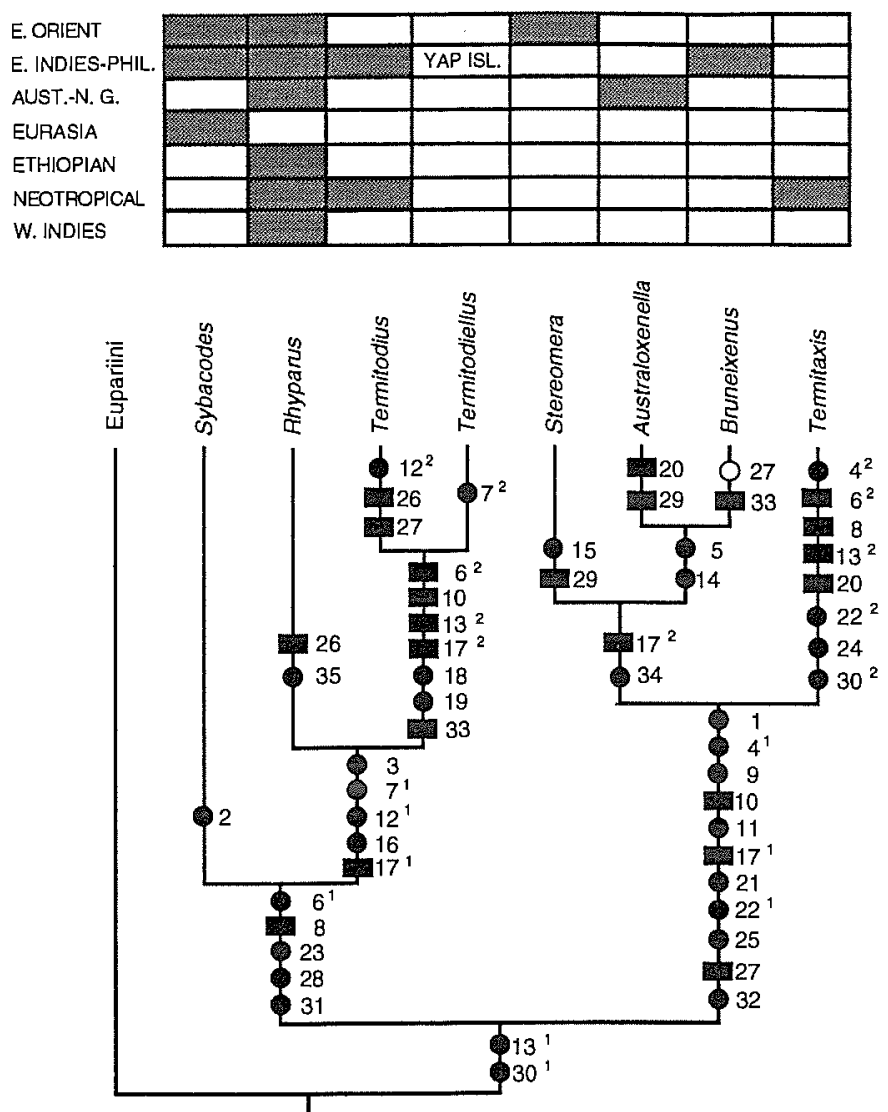

F1G. 36. Phylogeny of the Rhyparini and Stereomerini; the generalized distribution of each genus is indicated by darkened rectangles above the generic names. - apomorphy; , homoplasy; $O$, reversal.

are unique to the Rhyparini or Stereomerini combined, but the apomorphic states of 33 and 34 are restricted to the Stereomerini. The apomorphic character state of 31 appears to be restricted to the Rhyparini.

\section{Phylogeny}

In developing a phylogeny of the Rhyparini and Stereomerini we initially constructed a cladogram based on the information in Table 2. We then ran the same data through two different computer programs. We first used Hennig 86 (version 1.5 by James S. Farris, 1988), assisted by M. Sharkey, and then used phylogenetic analysis using parsimony (PAUP, version 3.0n by D. L. Swofford, 1991), assisted by R. Anderson and J. Heraty. Both programs produced a single most parsimonious tree that showed identical branching (Fig. 36) and matched our initial cladogram. Since PAUP has the advantage of allowing multistate taxa (i.e., 0 and 1 for characters 8 and 27 ) and can report the consistency index excluding autapomorphic states, we report only the figures produced using PAUP. Heuristic search methods were used and trees were rooted using the Eupariini (primarily Ataenius spp.) as the outgroup. Character-state transformations were derived using an accelerated transformation hypothesis (favouring reversals over parallelisms), although in some cases parallelisms were considered more likely (e.g., character 29).

The single most parsimonious tree produced by PAUP (with 56 steps and a consistency index (CI) of 0.750) is shown in Fig. 36). Characters 7,12 , and 22 were treated as ordered.

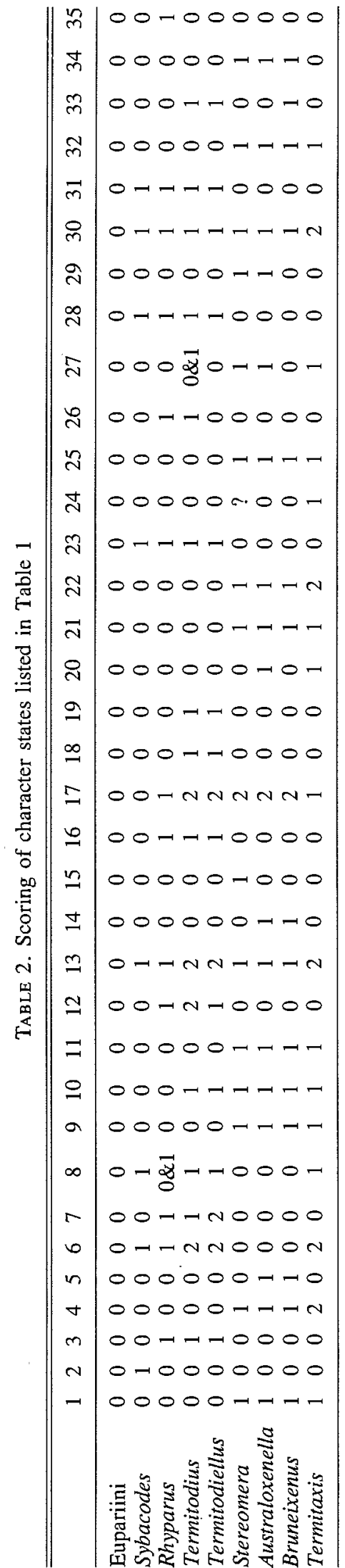


When character 24 was omitted because of missing data in Stereomera, there was little change in the CI and no change in the phylogeny. Longer trees (more steps) included the possibility that the Rhyparini and Stereomerini are not related (not monophyletic) and in another case that Sybacodes might be the out-group for the other seven genera, with the tribal groups otherwise unaltered. While this is a consideration, the shared (synaphomorphic) character states of the reduced scutellum, reduced tarsal spurs, six pronotal ridges, and the leg locking mechanisms all make this out-group placement unlikely.

In our proposed phylogeny, 10 characters $(6,8,10,13,17$, $20,26,27,29$, and 33) show possible parallelisms (homoplasy). These are indicated by rectangles on the cladogram. The hollow circle beside 27 under Bruneixenus in Fig. 36 represents a possible reversal. Additional autapomorphic characters that separate Bruneixenus from Australoxenella are not included in our analysis but are in the key to the genera and are included in the descriptions.

\section{Odd Eupariini and Aphodiini}

The genus Notocaulus Quedenfeldt (Fig. 32) has been included in the Rhyparini by most authors, but we believe that it belongs in the Eupariini. We base this placement on its large scutellum, well-developed tarsal spurs (Fig. 33), triangular posterior prosternal process, slender legs lacking locking devices, and the different configuration of the pronotal ridges (any similarity with the Rhyparini being convergent). Except for the ridges the other characters all belong to our "out-group."

Another genus showing some superficial similarities to the Rhyparini is Cartwrightia (Figs. 29, 30), which has elytral costae and bulbous elytral apices, pronotal ridges, etc. However, like Notocaulus, Cartwrightia has a large scutellum and a triangular prosternal process (Fig. 31) and belongs in the Eupariini. In addition to examining many genera in the Eupariini we checked genera with ridged elytra like Sybax Boheman (Fig. 34) in the Aphodiini to confirm our ideas on which characters might possibly be subject to convergence. After examining a number of different genera and examples of all of the currently recognized tribes of the Aphodiinae we conclude that the character states we have used to define the Rhyparini and Stereomerini, while showing evidence of homoplasy, are valid and rationalize the placement of these odd taxa. This is particularly true considering the difficulties that previous authors have encountered in determining their relationships.

\section{Habits and distribution patterns}

Only the habits of Termitodius (Reyes-Castillo and Martinez 1979), Termitodiellus (Nomura 1943), and Termitaxis (Krikken 1970) are definitely known; they are all associated with termites. On one occasion one of us (H.H.) collected a specimen of Rhyparus in Panama under the bark of a fallen log infested with termites, but this association may be simply a coincidence. As far as we can ascertain, most Rhyparus have been collected "at light." The single specimen of Australoxenella humptydooensis was collected in a light trap, but there is no indication of how specimens of Stereomera, Bruneixenus, or Sybacodes were taken.

From a comparison of the distribution patterns of the Rhyparini and Stereomerini (Fig. 36), coupled with their known habits, it could be concluded that the worldwide distribution of both tribes can be explained by their association with termites. Termites are at present concentrated in tropical habitats and are known to be an ancient group related to cockroaches (Kukalová-Peck 1991). Emerson (1955) describes the origins and distributional patterns of the termite genera, some of which are pan-tropical. Considering the assumed ancient origin of termites, their wide generic distributions may easily be explained by their having a Pangean origin. However, there is little direct evidence that termite inquilines are of equal age. According to Crowson (1981, p. 669), a scarabaeoid found in Lebanese amber (dated Lower Cretaceous) "is of special interest in showing features suggestive of termitophilous habits; termites are almost certainly the oldest group of "eusocial" insects, probably dating back to the Lower Cretaceous, and this fossil is the earliest evidence we have of the possible association of other insects with their nests." Crowson suggests that the fossil may belong to the small coleopteran family Karumiidae, but his illustration of it (Plate 9, Fig. D) also resembles, in some ways, the aphodiine tribe Corythoderini, which Tangelder and Krikken (1982) suggest may have origin ated in the early Tertiary.

Based on the above and on the supposition that several of the modern scarab lineages arose in the Jurassic (Crowson 1981), it does not seem unreasonable to postulate an early association of scarabs with termites. If the scarabaeoid inquilines have had a long association with termites, then the genera of highly modified Stereomerini occurring in Australia and South America may be relicts of a Gondwanian group, while the Rhyparini possibly had a slightly more recent, perhaps early to middle Tertiary, origin. The occurrence of Rhyparus on some oceanic islands, such as Mauritius, indicates a reasonble ability to disperse, a factor that may have contributed to both the number of extant species and their relatively wide range as a group. Obviously, more information is needed, both ecologically and taxonomically, before any real understanding of their distribution patterns is reached.

While slightly outside the scope of this study, it is interesting to note that the genera Euparia Serville, Euparixia Brown, Euparixoides Hinton, and Cartwrightia apparently form a natural group within the Eupariini. All of these genera appear to be myrmecophilous (Woodruff and Cartwright 1967).

\section{Acknowledgments}

We are indebted to Alice Wells, Northern Territory Museum of Arts and Sciences, and Malcolm Kerley, The Natural History Museum (formerly the British Museum (Natural History)) for the loan of material. Robert Anderson, Canadian Museum of Nature; John Heraty, A. T. Howden, Stewart Peck and Terry Wheeler, all of Carleton University; Mike Sharkey, Agriculture Canada; and Z. Stebnicka, the Polish Academy of Sciences, kindly assisted with or commented on various drafts of the manuscript. Lewis Ling, Carleton University, took the SEM micrographs and assisted with the plates. T. MacKechnie typed the various drafts of the manuscript. We sincerely thank all of the above for their contributions to this project. In addition to the support received from our respective institutions, this work has been supported by a Natural Sciences and Engineering Research Council of Canada operating grant to H. F. Howden.

Arrow, G. J. 1905. LXX. On some oriental aphodiid Coleoptera of the Rhyparus group, with description of a new genus. Ann. Mag. Nat. Hist. Ser. 7,15: 534-540.

Cartwright, O. L., and Woodruff, R. E. 1969. Ten Rhyparus from the western hemisphere (Coleoptera: Scarabaeidae: Aphodiinae). Smithson. Contrib. Zool. No. 21. pp. 1-20. 
Crowson, R. A. 1981. The biology of the Coleoptera. Academic Press, London.

Enerson, A. E. 1955. Geographical origins and dispersions of termite genera. Fieldiana Zool. 37: 465-521.

Krikken, J. 1970. Termitaxis holmgreni gen.nov., sp.nov., a blind, flightless termitophilous scarab from Peru (Coleoptera: Aphodiidae). Proc. K. Ned. Akad. Wet. Ser. C, 73: 469-476.

Kukalová-Peck, J. 1991. Fossil history and evolution of hexapod structures. Chap. 6. In The insects of Australia. 2nd ed. Edited by I. E. Naumann. Melbourne University Press, Carlton, Victoria. pp. 144-182.

Nomura, S. 1943. Zur Kenntnis der Aphodiiden aus Micronesia (Coleoptera: Scarabaeidae). Mushi, 15: 77-82.

Rakovič, M. 1987. A revision of the genus Odochilus Harold with remarks on the tribal classification of the subfamily Aphodiinae (Coleoptera, Scarabaeidae). Acta Entomol. Bohemoslov. 87: $27-$ 44.

Reyes-Castillo, P., and Martínez, A. 1979. Nuevos Rhyparini
Neotropicales, con notas sobre su biologia (Coleoptera, Scarabaeidae, Aphodiinae). Folia Entomol. Mex. 41: 115-133.

Schmidt, A. 1910. Coleoptera Lamellicornia Fam. Aphodiidae. Genera Insectorum Fasc. 110. Witsman.

Schmidt, A. 1922. Coleoptera. Aphodiinae. Das Tierreich, Part 45. Walter de Gruyter \& Co., Berlin.

Stebnicka, Z. 1985. A new genus and species of Aulonocneminae from India with notes on comparative morphology (Coleoptera: Scarabaeidae). Rev. Suisse Zool. 92: 649-658.

Tangelder, I. R. M., and Krikken, J. 1982. Termitophilous scarabs of the tribe Corythoderini: a taxonomic review (Coleoptera: Aphodiidae), Zool. Verh. (Leiden), No. 194.

Watrous, L. E., and Wheeler, Q. D. 1981. The out-group comparison method of character analysis. Syst. Zool. 30: $1-11$.

Woodruff, R. E., and Cartwright, O. L. 1967. A review of the genus Euparixia with description of a new species from nests of leafcutting ants in Louisiana (Coleoptera: Scarabaeidae). Proc. U.S. Natl. Mus. 123: 1-21. 